\title{
Isolasi Senyawa Bioaktif Antibakteri Pada Ekstrak Etanol Teripang Pasir (Holothuri scabra) Di Kepulauan Selayar
}

\author{
Yuliana, Asriani llyas, Suriani \\ Jurusan Kimia, Fakultas Sains dan Teknologi, UIN Alauddin Makassar \\ Email: yuliana.chemistry@yahoo.com
}

\begin{abstract}
Sand sea cucumber (Holothuria scabra) is one type of marine invertebrates with family Holothuriidae and is a member of Enchinodermata animals. Types of animals have been used as raw materials in traditional medicine. The aims of this reseach are to isolate the bioactive compounds contained in the ethanol extract of sand sea cucumbers and to know its major bioactivity. This research conducted in several methods namely extraction, fractionation, identification using thin layer chromatography (TLC) and qualitative test to determine secondary metabolites, as well as the characterization by FTIR. Results obtained from the isolation is a pure isolate by weight of 0.0203 grams of yellowish white paste. Purification was performed using three systems eluent as well as FTIR spectroscopy. The results showed that the compounds in pure isolates are alkaloids. Viscous extract and pure isolates subsequently tested its antibacterial test disc diffusion method using bacteria Salmonella thypi and Staphylococcus aureus. The results showed that the extract activity of the bacteria Salmonella thypi and Staphylococcus aureus into the strong category with optimum diameter of clear zone respectively $11.50 \mathrm{~mm}$ and $12.30 \mathrm{~mm}$.
\end{abstract}

Keyword: Bioaktive Compound, Disc Diffusion, Isolation, Sand Sea Cucumber (Holothuria scabra).

\section{PENDAHULUAN}

Indonesia dikenal sebagai negara kepulauan terbesar di dunia. Namun demikian, pengembangan di bidang kelautan hingga saat ini masih jauh dari harapan. Padahal wilayah pesisir dan pulau-pulau kecil di Kepulauan Indonesia memiliki keanekaragaman hayati laut yang sangat besar dan belum dimanfaatkan secara optimal. Salah satunya yaitu di kepulauan Selayar. Kepulauan Selayar merupakan pulau kecil yang membentang di kaki Sulawesi Selatan dengan luas wilayah lautannya sekitar $21.138,41 \mathrm{~km}^{2}$ (94, 68\%) dan wilayah daratannya sekitar 1.188,28 $\mathrm{km}^{2}(5,32 \%)$ (Syah, 2010). Pulau ini memiliki potensi sumber daya alam khususnya laut yang sangat bermanfaat bagi kehidupan manusia. Berbagai organisme laut seperti mikroorganisme, algae, sponge dan teripang merupakan sumber bahan aktif yang sangat potensial.

Selayar merupakan salah satu penghasil teripang terbanyak di Indonesia. Salah satu jenis teripang dihasilkan yaitu teripang pasir (Holothuria scabra). Teripang pasir memiliki tubuh berbentuk bulat memanjang menyerupai silinder berwarna abu-abu atau hitam dengan bagian tubuh atas keriput dan melintang berwarna gelap. Mulutnya ada pada salah satu ujung yang dikelilingi oleh kentakel atau lengan peraba yang kadang bercabang-cabang dan dubur pada ujung lainnya (Jaeger, 1883).

Teripang pasir telah lama digunakan sebagai obat tradisional di kalangan masyarakat tanpa mengetahui senyawa metabolit sekunder yang terkandung di dalamnya. Metabolit sekunder adalah 
senyawa yang ikut berperan penting dalam perlindungan makhluk hidup. Oleh sebab itu, maka dilakukanlah penelitian terhadap teripang pasir (H. scabra). Ekstrak etanol teripang pasir juga memiliki aktivitas antibakteri. Antibakteri merupakan zat-zat yang digunakan untuk menghambat pertumbuhan atau mematikan bakteri. Teripang pasir (H. scabra) telah dilaporkan mampu menghambat pertumbuhan bakteri Salmonella typhi (Amin, 2012). Selain itu, ekstrak etanol teripang pasir (H. scabra) juga berpotensi sebagai antibakteri terhadap Staphylococcus aureus dan Pseudomonas aeruginosa (Sitorus, 2015). Hasil penelitian lain juga menyebutkan bahwa ekstrak etil asetat teripang pasir (H. scabra) basah memiliki potensi sebagai antibakteri terhadap Pseudomonas aeruginosa Senyawa yang terkandung dalam ekstrak etil asetat teripang pasir yaitu saponin, steroid, triterpenoid, dan alkaloid (Nimah, 2012).

Pengujian terhadap senyawa antibakteri seringkali menggunakan pelarut etanol karena titik didihnya yang rendah sehingga lebih mudah untuk diuapkan dan melarutkan senyawa dengan cukup cepat serta memiliki harga yang terjangkau (Inayah, 2012). Bakteri uji yang digunakan dalam penelitian ini yaitu Staphylococcus aureus dan Salmonella thypi. Keduanya masingmasing merupakan bakteri gram positif dan gram negatif. Hal ini dilakukan untuk melihat perbedaan aktivitas ekstrak etanol teripang pasir pada kedua jenis bakteri tersebut. Aktivitas antibakteri teripang pasir dapat dilakukan secara in vitro dengan menggunakan metode difusi cakram (Roihanah, 2012).

\section{METODE PENELITIAN}

Alat

Alat-alat yang digunakan adalah spektrofotometer FTIR, autoclave, incubator, rotary evaporator, neraca analitik, oven, chamber, blender, Kromatogravi Kolom Cair Vakum (KKCV), lampu UV 254-366 nm, lampu pijar, kolom kromatografi gravitasi, jangka sorong, pipet skala, erlenmeyer, gelas kimia, cawan petri, tabung reaksi, pipet tetes, alat penyemprot, pipa kapiler, mikropipet, botol vial, wadah fraksi, lumpang dan mortal, plat tetes, pinset, toples,ose, penggaris, spoid $1 \mathrm{~mL}$ dan $5 \mathrm{~mL}$, tip kuning dan botol gelap.

\section{Bahan}

Bahan yang digunakan adalah akuabides, akuades, aluminium foil, asam sulfat $\left(\mathrm{H}_{2} \mathrm{SO}_{4}\right)$ $10 \%$, aseton $\left(\mathrm{C}_{3} \mathrm{H}_{6} \mathrm{O}\right)$, biakan murni bakteri Staphylococcus sureus dan Salmonella typhi, besi (III) klorida $\left(\mathrm{FeCl}_{3}\right) 5 \%$, dimetil sulfoksida (DMSO), etil asetat $\left(\mathrm{C}_{4} \mathrm{H}_{8} \mathrm{O}_{2}\right)$, kapas, kertas cakram, kloroform $\left(\mathrm{CHCl}_{3}\right)$, natrium hidroksida $(\mathrm{NaOH}) 10 \%$, media NA (Nutrient Agar) dan NB (Nutrient Broth), metanol $\left(\mathrm{CH}_{3} \mathrm{OH}\right)$, natrium klorida $(\mathrm{NaCl})$ murni, pelarut etanol $\left(\mathrm{C}_{2} \mathrm{H}_{6} \mathrm{O}\right)$ dan n-heksan $\left(\mathrm{C}_{6} \mathrm{H}_{14}\right)$, pereaksi Dragendroff pereaksi Lieberman-Burchard, pereaksi mayer, pereaksi wagner, silika $\mathrm{G}_{60}\left(230-400\right.$ mesh) Merck nomor katalog 7730, 7733 dan 7734, silika gel $\mathrm{G}_{60} \mathrm{PF}$ 254 dan spidol permanen, teripang pasir yang telah dikeringkan.

\section{Prosedur Kerja}

Ekstraksi

Al-Kimia | Volume 5 Nomor $12017 \mid 72$ 
Sampel teripang dipotong kecil-kecil kemudian dikeringkan di bawah sinar matahari. Teripang yang kering ditumbuk menggunakan mortar sampai menjadi ukuran yang lebih kecil kemudian diblender hingga sampel menjadi lebih halus. Teripang pasir yang telah dihaluskan ditimbang sebanyak $1 \mathrm{Kg}$, kemudian dimaserasi dengan pelarut etanol selama 1x24 jam (3 kali atau hingga diperoleh filtrat bening). Maserat yang diperoleh dipekatkan menggunakan evaporator sampai diperoleh ekstrak kental.

\section{Fraksinasi}

Ekstrak kental etanol yang diperoleh dianalisis menggunakan KLT dengan larutan pengembang (eluen) yaitu n-heksan:etil asetat dengan perbandingan 9:1 kemudian dilanjutkan dengan kromatografi kolom cair vakum dengan menggunakan silika sebagai fase diamnya. Fasa gerak yaitu larutan pengembang yang diperoleh dari hasil KLT yang kepolarannya terus ditingkatkan yaitu 100\% n-heksan tiga kali, n-heksan:etil asetat (9,5:0,5 tiga kali, 9:1 empat kali, 8:2 dua kali, 7:3 dua kali, $6: 4$ dua kali, 5:5 dua kali, 4:6, 3:7, 2:8, 9:1) dan 100\% metanol. Hasil fraksinasi ditampung dalam beberapa wadah kemudian dianalisis menggunakan KLT dengan eluen n-heksan:etil asetat 9:1. Fraksi-fraksi yang mempunyai nilai $R f$ yang sama digabung. Fraksi yang sudah digabung dan terdapat tanda kristal dilanjutkan pada kromatografi kolom gravitasi dengan perbandingan pelarut n-heksan:etil asetat 9:1 tujuh kali. Fraksi-fraksi yang dihasilkan dilanjutkan dengan uji KLT, uji kualitatif dan pemurnian.

\section{Pemurnian}

Pemurnian dilakukan dengan cara kristalisasi hingga diperoleh isolat murni yang berbentuk pasta berwarna putih kekuningan yang ditandai dengan hasil KLT yang menunjukkan satu noda dan pengujian tiga sistem eluen dengan menggunakan eluen n-heksan:kloroform (5:5), nheksan:etil asetat (9:1) dan kloroform:etil asetat (2:8). Isolat murni dengan identifikasi menggunakan uji kualitatif yang dilanjutkan karakterisasi dengan menggunakan alat spektrofotometer FTIR serta uji antibakteri.

\section{Identifikasi Senyawa}

\section{Uji Alkaloid}

Percobaan ini dilakukan dengan cara larutan uji dipipet ke dalam plat tetes dan ditambahkan pereaksi meyer dan wagner kemudian diamati perubahan warna yang terjadi yaitu terdapat endapan putih atau kuning (meyer) dan endapan coklat (wagner).

\section{Uji Terpenoi dan Steroid}

Percobaan ini dilakukan dengan cara larutan uji dipipet ke dalam plat tetes dan ditambahkan pereaksi lieberman burchard kemudian diaamati perubahan warna yang terjadi yaitu berwarna merah-ungu (terpenoid) dan biru atau hijau (steroid).

\section{Uji flavonoid}
a. $\mathrm{NaOH} 10 \%$ 
Percobaan ini dilakukan dengan cara larutan uji dipipet ke dalam plat tetes dan ditambahkan $\mathrm{NaOH} 10 \%$ dan diamati perubahan warna yang terjadi dengan mengamati dari kuning tua sampai menjadi kuning muda.

b. $\mathrm{H}_{2} \mathrm{SO}_{4}$ pekat

Percobaan ini dilakukan dengan cara sampel diencerkan dengan beberapa $\mathrm{mL}$ alkohol kemudian dipipet ke dalam plat tetes dan ditetesi dengan $\mathrm{H}_{2} \mathrm{SO}_{4}$ pekat. Perubahan warna yang terjadi diamati dari kuning tua menjadi merah tua.

c. $\mathrm{FeCl}_{3}$

Percobaan ini dilakukan dengan cara sampel diencerkan dengan beberapa $\mathrm{mL}$ alkohol kemudian dipipet ke dalam plat tetes dan ditetesi dengan $\mathrm{FeCl}_{3}$. Perubahan warna yang terjadi adalah biru hitam atau hijau kekuningan.

\section{Uji Saponin}

Percobaan ini dilakukan dengan cara sampel ekstrak teripang pasir sebanyak 0,5 gram ditambahkan dengan $10 \mathrm{~m}$ aquades, kemudian dipanaskan selama 5 menit. Larutan dituang ke dalam tabung reaksi dalam keadaan panas. Larutan diambil sebanyak $5 \mathrm{~mL}$ kemudian dikocok dengan kuat secara vertikal selama 10 detik. Adanya saponin ditandai dengan terbentuknya busa yang stabil setinggi $1-10 \mathrm{~cm}$ selama 10 menit.

\section{Karakterisasi dengan Spektrofotometer FTIR}

Isolat murni diambil sebanyak $1 \mathrm{mg}$, kemudian dicampurkan $\mathrm{KBr}$ dengan cara digerus sampai homogen. Campuran tersebut dimasukkan ke dalam alat pembuat pellet dengan tekanan $74 \mathrm{mmHg}$ dan waktu 5 menit sehingga diperoleh pellet yang ketebalannya $\pm 1 \mathrm{~mm}$. Plat diletakkan pada wadah plat kemudian diukur serapannya dengan alat FTIR.

\section{Uji Aktivitas Antibakteri menggunakan Metode Difusi Cakram}

\section{Sterilisasi Alat}

Alat-alat yang akan digunakan disterilkan dengan cara dimasukkan ke dalam autoklaf selama 15 menit pada suhu $121^{\circ} \mathrm{C}$ dan tekanan 15 psi (per square inchi).

\section{Pembuatan Nutrient Agar}

Pembuatan media nutrient agar dilakukan dengan nutrient agar sebanyak 4,6 g dilarutkan dalam $200 \mathrm{~mL}$ akuades pada beaker gelas. Suspensi dipanaskan sampai mendidih, kemudian dimasukkan dalam erlenmeyer kemudian ditutup dengan kapas dan wrap kemudian disterilisasi. Proses sterilisasi digunakan autoklaf pada suhu $121^{\circ} \mathrm{C}$ dengan tekanan 15 psi selama 15 menit (Volk dan Wheeler, 1993).

\section{Pembuatan Nutrient Broth}

Pembuatan media dilakukan dengan nutrient broth $0,9 \mathrm{~g}$ dilarutkan dalam $100 \mathrm{~mL}$ akuades pada beaker gelas. Suspensi yang dihasilkan dipanaskan sampai mendidih, kemudian dimasukkan dalam erlenmeyer ditutup dengan kapas dan wrap kemudian disterilisasi. Proses sterilisasi digunakan autoklaf pada suhu $121^{\circ} \mathrm{C}$ dengan tekanan 15 psi selama 15 menit. 


\section{Pembuatan Larutan Biakan Aktif}

Bakteri dibiakkan dengan cara diambil satu ose bakteri hasil peremajaan biakan murni dan dimasukkan dalam $10 \mathrm{~mL}$ media agar cair steril dan dihomogenkan. Larutan ini berfungsi sebagai biakan aktif.

\section{Uji Aktivitas Antibakteri}

Uji aktivitas antibakteri dengan ekstrak etanol dan isolat murni digunakan konsentrasi 250 ppm, 500 ppm, 750 ppm dan 1000 ppm. Kertas cakram (diameter 5 mm) diserapkan ekstrak etanol dan isolat murni. Proses penyerapannya dilakukan dengan cara kertas cakram direndam pada ekstrak etanol dan isolat murni tersebut selama 30-60 menit. Mengambil larutan biakan aktif bakteri sebanyak $50 \mu \mathrm{L}$ dan dimasukkan ke dalam cawan petri steril. Media agar padat dipanaskan sampai mencair, kemudian didinginkan sampai suhu $40^{\circ} \mathrm{C}$ dan dituang ke dalam cawan petri yang berisi larutan biakan aktif bakteri. Media agar padat dihomogenkan dan larutan biakan aktif bakteri dan dibiarkan hingga memadat. Kertas cakram dilektakkan di atas permukaan media bakteri menggunakan pinset dan ditekan sedikit. Selanjutnya, diinkubasi pada suhu $37^{\circ} \mathrm{C}$ selama \pm 24 jam. Kemudian, zona hambatannya diukur dengan menggunakan jangka sorong. Luas zona hambatan ditentukan dengan cara diameter keseluruhan (cakram + zona hambatan) dikurangi dengan diameter cakram dan diameter zona hambat pelarut.

\section{HASIL DAN PEMBAHASAN}

\section{Ekstraksi}

Teripang pasir dibersihkan dan dikeringkan di bawah sinar matahari yang tidak terlalu panas. Hal ini dilakukan untuk mengurangi kadar air teripang pasir dan mencegah pembusukan pada teripang pasir. Teripang pasir yang kering kemudian dibuat dalam ukuran yang lebih sederhana untuk memberikan luas permukaan yang besar pada sampel. Sampel dengan ukuran sederhana akan membuat pelarut yang digunakan semakin mudah menarik senyawa metabolit sekunder. Pelarut yang digunakan yaitu etanol. Hal ini disebabkan karena pelarut etanol merupakan pelarut yang dapat melarutkan senyawa-senyawa metabolit sekunder yang polar dan senyawa yang memiliki tingkat kepolaran yang rendah (Agoes, 2007). Maserasi dilakakukan selama 1x24 jam (3 kali) dan menghasilkan maserat yang berwarna kuning bening. Maserat yang diperoleh kemudian dievaporasi untuk mendapatkan ekstrak kental etanol teripang pasir. Ekstrak kental yang diperoleh yaitu 57,0791 gram.

\section{Fraksinasi}

Ekstrak kental yang diperoleh selanjutnya dilakukan analisis menggunakan uji kromatografi lapis tipis yang bertujuan untuk mengetahui eluen yang baik untuk proses fraksinasi awal kromatografi cair vakum. Eluen yang digunakan yaitu eluen dengan perbandingan pelarut nheksan:etil asetat (9:1). Eluen ini dipilih karena mampu memisahkan noda pada plat KLT dengan baik dan noda tertinggi memiliki $\mathrm{Rf}=0,3$. Plat KLT yang digunakan memiliki fase diam berupa silika $\mathrm{G}_{60}$ PF 254. Noda yang dihasilkan dari proses elusi dapat dilihat menggunakan lampu UV 
dengan panjang gelombang 254-336 $\mathrm{nm}$ dan cairan penampak noda $\mathrm{H}_{2} \mathrm{SO}_{4}$ 10\%. Cairan penampak ini dipilih karena diketahui merupakan penampak noda yang umum untuk senyawa metabolit primer maupun senyawa metabolit sekunder (Firdaus, 2011). Kromatografi kolom cair vakum menggunakan dua jenis silika yang berbeda yaitu silika $\mathrm{G}_{60}$ Merc nomor katalog 7730 sebagai fase diam dan silika $\mathrm{G}_{60}$ Merc nomor katalog 7733 diimpreg bersama ektrak kental. Eluen yang digunakan dalam kromatografi cair vakum yaitu n-heksan $100 \%$ tiga kali, nheksan:etil asetat (9,5:0,5 tiga kali, 9:1 empat kali, 8:2 dua kali, 7:3 dua kali, 6:4 dua kali, 5:5 satu kali, 4:6 satu kali, 3:7 satu kali, 2:8 satu kali, 1:9 satu kali) dan 100\% metanol.

Fraksi yang diperoleh dari hasil fraksinasi awal yaitu sebanyak 22 fraksi. Fraksi-fraksi tersebut selanjutnya di KLT dengan eluen n-heksan:etil asetat (9:1) dan yang memiliki penampakan noda yang sama pada KLT digabung menjadi fraksi-fraksi utama. Fraksi utama tersebut terdiri dari fraksi A, fraksi B, fraksi C, fraksi D dan fraksi E dan F. Dari keenam fraksi tersebut, fraksi yang dilanjutkan yaitu fraksi $\mathrm{E}$ dengan pertimbangan noda yang dihasilkan lebih sederhana dan bobotnya lebih besar daripada fraksi yang lain. Fraksi tersebut belum murni, sehingga dilakukan pemurnian melalui kromatografi kolom gravitasi.

Kromatografi kolom gravitasi bertujuan untuk mendapatkan senyawa murni. Kromatografi kolom gravitasi memiliki prinsip yang sama dengan kromatografi kolom cair vakum yaitu sampel dielusi dengan eluen yang memiliki tingkat kepolaran yang rendah sampai pada eluen yang memiliki tingkat kepolaran yang tinggi. Fase diam berupa silika $\mathrm{G}_{60}$ Merck nomor katalog 7734. Eluen yang digunakan yaitu perbandingan pelarut n-heksan:etil asetat (9:1 sebanyak 7x). Fase gerak ini dibiarkan mengalir melalui kolom gravitasi, yang mana setiap komponen senyawa terlarut akan bergerak dengan laju yang berbeda, memisah dan dikumpulkan berupa fraksi ketika keluar dari kolom (Yazid, 2005). Hasil kromatografi kolom gravitasi yaitu 33 fraksi. Fraksifraksi tersebut dilanjutkan dengan analisis KLT untuk melihat penampakan noda yang sama. Penggabungan fraksi menghasilkan 2 fraksi utama. Fraksi yang dilanjutkan untuk pemurnian adalah fraksi Eb.

\section{Pemurnian}

Pemurnian merupakan tahap akhir isolasi. Kemurnian suatu isolat senyawa dapat diketahui dengan melakukan uji kemurnian tiga sistem eluen pada hasil pemisahan dengan analisis kromatografi lapis tipis hingga tampak satu noda. Noda tunggal yang timbul menandakan isolat suatu senyawa dapat dikatakan seagai isolat senyawa murni. Eluen yang digunakan adalah perbandingan n-heksan:kloroform (5:5), n-heksan:etil asetat (9:1) dan kloroform:etil asetat (2:8). $\mathrm{Rf}$ masing-masing noda tunggal yaitu eluen n-heksan:kloroform (5:5) memiliki Rf 0,28, eluen nheksan:etil asetat (9:1) memiliki $\mathrm{Rf}$ 0,6 dan eluen kloroform:etil asetat (2:8) memiliki $\operatorname{Rf}$ 0,9. Berdasarkan hasil yang Rf yang dimiliki masing-masing noda, dapat dikatakan bahwa isolat senyawa sudah murni. 


\section{Identifikasi}

Hasil uji kualitatif menunjukkan bahwa ekstrak etanol teripang pasir mengandung senyawa metabolit sekunder berupa flavonoid, saponin dan alkaloid. Hal ini dapat diketahui karena terjadinya perubahan warna pada ekstrak menjadi berwarna kuning muda pada pereaksi $\mathrm{NaOH}$ $10 \%$ yang menunjukkan ekstrak positif mengandung senyawa metabolit sekunder berupa flavonoid. Penambahan pereaksi meyer terbentuk endapan putih dan pada pereaksi wagner terbentuk endapan coklat yang menunjukkan bahwa ekstrak mengandung senyawa metabolit sekunder berupa alkaloid. Sedangkan saponin ditandai dengan timbulnya busa setelah ekstrak ditambahkan aquabides yang dipanaskan dan dikocok. Identifikasi selanjutnya adalah uji kualitatif terhadap isolat senyawa murni, berdasarkan pengamatan dapat diketahui bahwa isolat murni mengandung senyawa alkaloid yang ditandai dengan terbentuknya endapan coklat setelah penambahan pereaksi wagner pada isolat murni.

\section{Karakterisasi dengan Spektrofotometer FTIR}

Spektrofotometer FTIR merupakan alat yang digunakan untuk mendapatkan spektrum inframerah dari absorbansi pada sampel yang digunakan untuk mengetahui jenis gugus fungsi dalam suatu jaringan hewan maupun tumbuhan yang diisolasi.

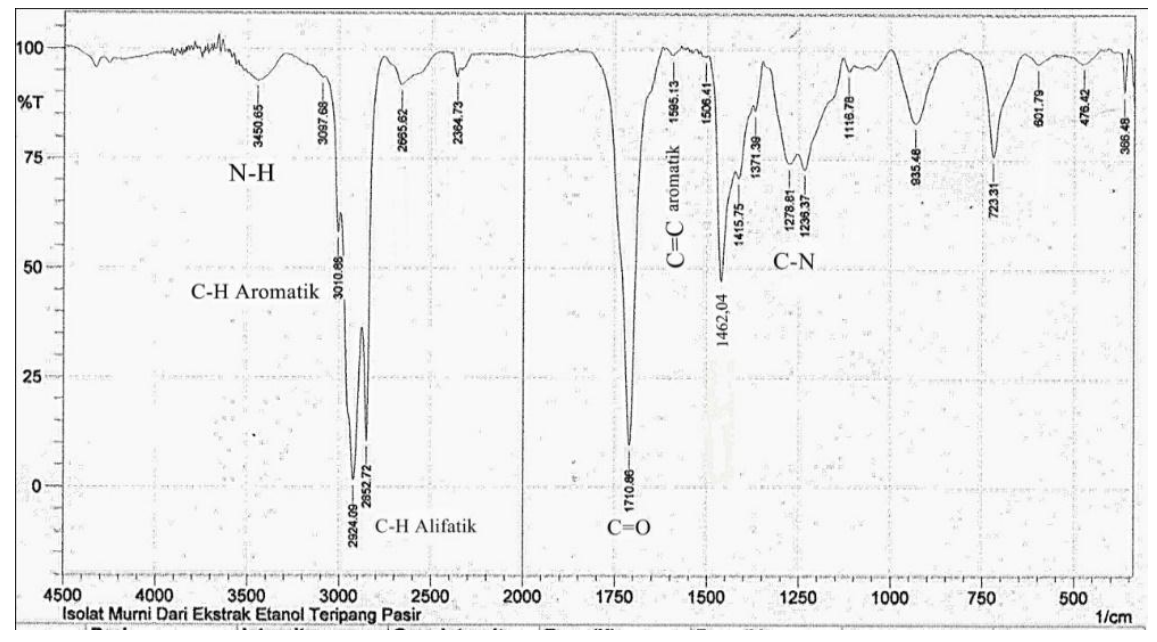

Gambar 1. Spektrum Inframerah (IR) Isolat Murni

Hasil karakterisasi IR terhadap isolat murni memperlihatkan adanya serapan-serapan yang khas untuk beberapa gugus fungsi, diantaranya adalah pada daerah bilangan gelombang 3450,65 $\mathrm{cm}^{-1}$ menunjukkan adanya serapan lemah sebagai vibrasi regang amina sekunder $(\mathrm{N}-\mathrm{H})$ yang sering muncul sangat lemah dan memunculkan satu pita dan didukung oleh adanya vibrasi C-N pada bilangan gelombang 1278,81-1236,37 $\mathrm{cm}^{-1}$. Vibrasi pada bilangan gelombang 1595,13$1585,41 \mathrm{~cm}^{-1}$ menunjukkan vibrasi $\mathrm{C}=\mathrm{C}$ aromatik. Hal ini didukung oleh munculnya serapan lemah pada panjang gelombang $3010,88 \mathrm{~cm}^{-1}$ yang menunjukkan adanya vibrasi regang $\mathrm{C}-\mathrm{H}$ 
aromatik dan muncul serapan pada bilangan gelombang $935,48 \mathrm{~cm}^{-1}$ yang menunjukkan vibrasi senyawa aromatik benzen 1,3-disubstitusi. Vibrasi pada bilangan gelombang 2924,09 $\mathrm{cm}^{-1}$ dan $2852,72 \mathrm{~cm}^{-1}$ menunjukkan pita tajam dengan intensitas kuat mengindikasikan keberadaan gugus C-H alifatik dan pada bilangan gelombang $1462,04 \mathrm{~cm}^{-1}$ dan $1415,76 \mathrm{~cm}^{-1}$ juga muncul vibrasi C-H alifatik. Serta serapan khas tajam pada bilangan gelombang 1710,86 menunjukkan adanya vibrasi regang $\mathrm{C}=\mathrm{O}$ (Silverstein, 2005).

Berdasarkan data spektroskopi IR dapat diketahui bahwa senyawa yang terdapat dalam isolat murni yang mempunyai vibrasi gugus amina sekunder $(\mathrm{N}-\mathrm{H})$, gugus $\mathrm{C}-\mathrm{H}$ aromatik, gugus $\mathrm{C}-\mathrm{H}$ alifatik, gugus $\mathrm{C}=\mathrm{O}$ dan gugus aromatik mengindikasikan sebagai senyawa alkaloid.

\section{Uji Antibakteri menggunakan Metode Difusi Cakram}

Hasil uji sensitivitas bakteri Salmonella thypi dan Staphylococcus aureus dapat dilihat pada tabel 1 di bawah ini:

Tabel 1. Uji Aktivitas Antibakteri terhadap Salmonella thypi dan Staphylococcus aureus

\begin{tabular}{|c|c|c|c|c|}
\hline \multirow{2}{*}{ No. } & \multirow{2}{*}{ Sampel } & \multirow{2}{*}{$\begin{array}{c}\text { Konsentrasi } \\
(\mathbf{p p m})\end{array}$} & \multicolumn{2}{|c|}{ Diameter Zona Bening (mm) } \\
\hline & & & Salmonella thypi & Staphylococcus aureus \\
\hline \multirow{4}{*}{1} & \multirow{4}{*}{ Ekstrak kental } & 1000 & 11,50 & 0,00 \\
\hline & & 750 & 8,40 & 12,30 \\
\hline & & 500 & 6,20 & 10,60 \\
\hline & & 250 & 0,00 & 0,00 \\
\hline \multirow{4}{*}{2} & \multirow{4}{*}{ Isolat murni } & 1000 & 0,00 & 10,70 \\
\hline & & 750 & 0,00 & 0,00 \\
\hline & & 500 & 0,00 & 0,00 \\
\hline & & 250 & 0,00 & 0,00 \\
\hline 3 & Kloramfenikol & & 25,00 & 22,33 \\
\hline 4 & DMSO & & 0,00 & 0,00 \\
\hline
\end{tabular}

Berdasarkan tabel di atas, ekstrak kental memberikan diameter daya hambat terhadap Salmonella thypi yaitu pada konsentrasi 1000 ppm memiliki daya hambat $11,50 \mathrm{~mm}$, pada konsentrasi $750 \mathrm{ppm}$ memiliki daya hambat $8,40 \mathrm{~mm}$ dan pada konsentrasi $500 \mathrm{ppm}$ memiliki daya hambat 6,20 mm. Sedangkan terhadap Staphylococcus aureus diameter daya hambat pada konsentrasi $1000 \mathrm{ppm}$ adalah $0,00 \mathrm{~mm}$, pada konsentrasi $750 \mathrm{ppm}$ memiliki diameter daya hambat 12,30 dan pada konsentrasi $500 \mathrm{ppm}$ memberikan diameter daya hambat 10,60 ppm. Isolat murni tidak membentuk zona hambat terhadap $S$. typhi sedangkan pada $S$. aureus membentuk diameter daya hambat $10,70 \mathrm{~mm}$ pada konsentrasi $1000 \mathrm{ppm}$. Hal ini disebabkan karena isolat murni mengandung senyawa alkaloid yang diketahui mampu menghambat pertumbuhan bakteri gram positif seperti $S$. aureus. Sehingga isolat murni tidak memiliki sensitivitas terhadap $S$. typhi.

Nomor 3 dan 4 pada Tabel 1 di atas merupakan uji kontrol. Kloramfenikol merupakan uji kontrol positif dan DMSO merupakan uji kontrol negatif. Uji tersebut dilakukan sebagai kontrol 
untuk melihat pengaruh dan tidak berpengaruhnya suatu senyawa terhadap bakteri $S$. typhi. Uji kontrol negatif untuk membuktikan bahwa DMSO tidak berpengaruh terhadap pertumbuhan bakteri S. typhi. Uji kontrol positif dilakukan untuk membuktikan bahwa kloramfenikol berpengaruh terhadap pertumbuhan bakteri $S$. typhi. Hasil uji cakram antibiotik kloramfenikol terbukti memiliki daya hambat dengan nilai 25,00 mm terhadap $S$. typhi dan 22,33 mm terhadap S. aureus. Besar diameter daya hambat pada kloramfenikol telah membuktikan bahwa senyawa yang memiliki antibiotik terbukti mampu menghambat pertumbuhan bakteri $S$. typhi maupun $S$. aureus. Sedangkan hasil zona hambat kontrol negatif terhadap kedua bakteri uji adalah 0,00 mm. Hal ini menunjukkan bahwa penggunaan pelarut DMSO tidak mempengaruhi hasil uji antibakteri dari ekstrak maupun isolat murni.

Pada uji daya hambat antibakteri, terdapat empat kategori yaitu kategori sangat kuat ( $\geq 20$ $\mathrm{mm})$, kuat $(10-20 \mathrm{~mm})$, sedang $(5-10 \mathrm{~mm})$, dan lemah $(\leq 5 \mathrm{~mm})$. Berdasarkan tabel 1 dapat diketahui efek daya hambat dari ekstrak etanol teripang pasir terhadap bakteri $S$. thypi dan $S$. aureus masuk dalam kategori kuat. Pada sampel isolat murni tidak ditemukan adanya daya hambat bakteri terhadap S. thypi, sedangkan pada S. aureus sampel isolat mampu memberikan daya hambat dan masuk dalam kategori kuat.

Senyawa pada ekstrak etanol dan isolat murni dari teripang pasir memiliki potensi sebagai antibakteri. Falvonoid merupakan senyawa yang baik untuk menghambat pertumbuhan bakteri dengan cara mendenaturasi protein. Flavonoid juga mampu merusak membran plasma karena dapat bereaksi dengan fosfolipid pada sel bakteri. Saponin memberikan efek utama terhadap bakteri dengan melakukan pelepasan protein dan enzim dari dalam sel. Alkaloid juga berpotensi sebagai antibakteri karena dapat merusak dinding sel. Staphylococcus aureus merupakan gram positif yang memiliki lapisan peptidoglikan tebal. Sehingga lebih sensitif terhadap senyawasenyawa yang punya potensi merusak atau menghambat sintesis dinding sel (Nimah, 2012).

\section{PENUTUP}

\section{Kesimpulan}

Kesimpulan pada penelitian ini yaitu sebagai berikut:

1. Jenis senyawa bioaktif antibakteri yang terdapat dalam ekstrak etanol teripang pasir adalah senyawa alkaloid.

2. Bioaktivitas antibakteri dari ekstrak etanol teripang pasir terhadap bakteri Salmonella thypi dan Staphylococcus aureus masuk dalam kategori kuat.

\section{Saran}

Saran dalam penelitian ini yaitu sebagai berikut:

1. Sebaiknya peneliti berikutnya melakukan uji lanjut seperti GC-MS, NMR sehingga struktur senyawa murninya dapat diketahui dengan jelas. 
2. Sebaiknya untuk penelitian berikutnya digunakan jenis pelarut lain seperti n-heksan untuk melihat perbedaan bioaktivitas antibakteri terhadap Staphylococcus aureus dengan menggunakan etanol seperti yang dilakukan dalam penelitian ini.

\section{DAFTAR PUSTAKA}

Agoes, Goeswin, 2007, Teknologi Bahan Alam, Bandung: ITB.

Amin, Feffianna M. et. al., 2012, "Daya Antibakteri Ekstrak Teripang Pasir (Holothuria Scabra) terhadap Pertumbuhan Bakteri (Salmonella Typhi) secara In Vitro" Jurnal Penelitian, h. 1-9, Online, http://download.portalgaruda.org/article.pdf (18 November 2015).

Firdaus, 2011, Laporan Hibah Penulisan Buku Ajar Teknik dalam Laboratorium Kimia Organik. Makassar: Unhas.

Inayah, Nurul, et. al., 2012, "Uji Toksisitas dan Identifikasi Awal Golongan Senyawa Aktif Ekstrak Etanol dan N-Heksana Teripang Pasir (Holothuria scabra) Kering Pantai Kenjeran Surabaya” Jurnal Alchemy, 2 (1): 92-100

Jaeger, 1883, De Holothuriis, Australia: ETI Biofarmati.

Nimah, Shopiatun, et. al., 2012, Uji Bioaktivitas Ekstrak Teripang Pasir (Holothuria Scabra) terhadap Bakteri Pseudomonas Aeruginosa dan Bacillus Cereus, Jurnal Perikanan, 1 (2): 19

Roihanah, et. al., 2012, Aktivitas Antibakteri Ekstrak Teripang Holothuria sp. terhadap Bakteri Vibrio harveyi secara In vitro, Journal of. Experimental Life Science. 1 (2): $1-5$,

Sitorus, Asrika Mutiara, 2015 "Uji Aktivitas Antibakteri Ekstrak N-Heksana, Etil Asetat dan Etanol Teripang di Pulau Sumatra Utara (Holothuria Scabra Jaeger) terhadap Staphylococcus aureus dan Pseudomonas aeruginosa" Pharmacology, Online, http://repository.usu.ac.id/handle/123456789/53875 (16 Februari 2016).

Syah, Firman, 2010, Selayar dan Pergerakan A. G. H. Hayyung (Pemberontakan Terhadap Kungkungan Budaya dan Penjajahan), Selayar: Pemda Kabupaten Kepulauan Selayar Bekerja Sama dengan LP2MT.

Yazid, Eztien, 2005, Kimia Fisika untuk Paramedis, Yogyakarta: Andi Offset. 